\title{
Bacchus, Augustus and the poet in Horace Odes 3.25
}

\author{
Lya Serignolli \\ University of São Paulo
}

\section{Introduction}

As a god of sympotic pleasures and enjoyment, Bacchus naturally fits into Horace's lyric poetry. ${ }^{1}$ The god's sacred drink, libera vina (liberating wines), is included in the Ars Poetica among the subjects assigned by the Muse to be sung in lyric verse. ${ }^{2}$ Horace presents Bacchus (also called Lenaeus/ Liber/ Lyaeus) not only as a sympotic deity, but also as a deified hero and patron of poetry. Bacchus' presence is particularly remarkable

1 For recent research on Bacchus in Horace, cf.: Harrison (2017) on the parallels between Bacchus, Horace and Augustus in C. 2.19; Giusti (2016) on the connections between Dionysiac themes, politics and dithyramb in Epode 9; Feldherr (2010) on the politics of representation through the image of Cleopatra in C. 1.37; Davis $(2010,116-121)$ on the Dionysiac aspects of Horace's lyric ethos; Schiesaro (2009) on the functions of Bacchus as a god of poetry in Horace's Odes. See also: Batinski (1991), Silk (1969), Commager (1957).

2 Hor., Ars Po. 83-85: Musa dedit fidibus ... libera vina referre; see also $C$ 1.32.9: Liberum et ... canebat ... barbite ... decus Phoebi. 
in the Odes, in which three poems are entirely dedicated to this god: $1.18,2.19$ and $3.25 .^{3}$

Odes 3.25 focuses on the poet's approach to Bacchus as his patron of poetry. Horace compares his poetic persona to a Bacchant, who is dragged to the remote landscapes of Bacchus only to give shape to a poem about the apotheosis of Augustus. Horace stresses the pleasure and danger of being committed to Lenaeus, a paradox that suits the god's ambivalent nature. In this paper, my aim is to discuss the associations between Bacchus, Augustus and Horace's lyric persona in Odes 3.25. ${ }^{4}$ First, I shall investigate the ambiguities and paradoxes of the state of Dionysiac possession as a metaphor for poetic enthusiasm in Horace's lyric poetry. Secondly, I will observe the identification between Horace's lyric persona and Augustus through their connections with Bacchus. I will suggest possible reasons for Horace's choice of Bacchus as a patron of poetry in this poem in praise of Augustus, where other divinities, such as Apollo or the Muses, would apparently seem a more suitable choice for this role. ${ }^{5}$ Finally, I will examine the role of Bacchus in an issue much discussed by scholars regarding Odes 3.25, which is whether Horace is announcing another poem when he says that he will sing praises of Augustus. I intend to show how Horace's

3 For Bacchus and Bacchic motifs in Horace, cf. Sat. 1.4.89; Epod. 9.38, 11.13; C. 1.1.29-32; 1.7.3, 23; 1.12.22; 1.16.7; 1.18; 1.19.2; 1.27.3; 1.32.9; 1.37.1, 32; 2.6.19; 2.11.17; 2.19; 3.3.13; 3.8.9; 3.21.16, $21 ; 3.25 ; 4.8 .34 ; 4.12 .14 ; 4.15 .26$; Epist. 1.19.4; 2.1.5; 2.2.78.

4 For research on Hor., C. 3.25, cf.: West (2002, 207-213), Oliensis (1998, 127131), Lowrie (1997, 317-325), Quinn (1980,285-287), Nisbet and Rudd (2004, 296-309), Parker (1992, 304-309), Connor (1971), Aricò (1985), Fraenkel (1957, 257-260), Xynue (2015, 156-161), Harrison (1998, 675).

5 For Apollo as Horace's patron of poetry, cf.: Hor., C.1.31.1; 3.4.4; 4.15.2; 4.6.2930: spiritum Phoebus mibi, Phoebus artem carminis nomenque dedit poetae. For the choice of Bacchus instead of Apollo in Hor., C. 2.19, see Stephen Harrison (forthcoming, 2017). For Horace as a poet of the Muses: Hor., C. 1.6.10; 3.1.3: Musarum sacerdos; 3.4.21: vester, Camenae, vester. 
approach to Bacchus in this ode reflects on issues of genre and on the treatment of Augustus as a theme of lyric poetry.

\section{Dionysiac poetics in Odes 3.25}

Bacchus is a god of many names, whose etymology can be associated with some of his traits. So I would like to start my analysis by looking at how the names chosen by Horace to refer to Bacchus in Odes 3.25 allude to the main themes explored in the poem. The poem starts with the god being addressed as Bacchus, a name that is associated with the frenzy and madness of Dionysiac revels and orgies. ${ }^{6}$ Bacchus is also called Naiadum Baccharumque potens (ruler of the Naiads and of the Bacchants), a periphrasis that stresses his power as the leader of an entourage of female followers. At the end the poem, he is invoked as Lenaeus, a name of Greek origin that is connected with his roles as god of the wine press, patron of the Lenaia (a Greek festival with dramatic competitions) and leader of the Maenads (also called Lenai). ${ }^{7}$ Horace's choice of these names is in tune with the contents of the poem, which is about Dionysiac possession, maenadism and poetic composition:

$6 \quad$ See Hor., C. 2.7.27: bacchabor, Plaut., Am. 2.2.71: Baccha bacchans. For the meanings and uses of words Bacchus and Bacchants, see Schlesier (1993, 93-94); Pailler (1995, 112-114).

7 Before Horace, Virgil attributes to Lenaeus the role of god of poetry, stressing his connections with theatre and agriculture: Virg., Georg. 2.7-8: huc, pater o Lenaee, ueni, nudataque musto tinge nouo mecum dereptis crura coturnis. For Bacchus/ Lenaeus as god of the wine press: Virg., Georg. 2.4; Ov., Met. 4.14; Servius, Vergilii Aeneidos Libros 4.207.9-10: nam Liber Lenaeus dicitur, quia torculis

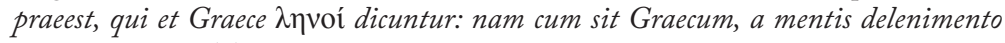
non potest accipi. Tib 2.3.63: et tu, Bacche tener, iucundae consitor uvae. Lenaeus in sympotic contexts: Virg., Aen. 4.207: gens epulata toris Lenaeum libat honorem. Tib. 3.6.38: Odit Lenaeus tristia verba pater. For Bacchus in Virgil's Georgics, cf.: F. Mac Góráin (2014). "The Mixed Blessings of Bacchus in Virgil's Georgics.”In: Dictynna 11. For the Lenaia and the Lenai, cf.: Guía (2013, 100-117); Seaford $(2011,39)$. 
Quo me, Bacche, rapis tui plenum? quae nemora aut quos agor in specus velox mente nova? quibus antris egregii Caesaris audiar aeternum meditans decus stellis inserere et consilio Iovis?

dicam insigne, recens, adhuc indictum ore alio. non secus in iugis exsomnis stupet Euhias

Hebrum prospiciens et nive candidam

Thracen ac pede barbaro lustratam Rhodopen, ut mihi devio ripas $^{8}$ et vacuum nemus mirari libet. o Naiadum potens

Baccharumque valentium proceras manibus vertere fraxinos, nil parvum aut humili modo, nil mortale loquar. dulce periculum est, o Lenaee, sequi deum cingentem viridi tempora pampino.

Where are you hurrying me, Bacchus, full as I am, of you? Into what woods, what caves, am I being driven at such speed in a strange state of mind? In what grotto shall I be heard as I practise setting the eternal glory of peerless Caesar among the stars and in the council of Jove? I shall sing on a momentous theme, that is modern and has never been sung by another's lips. Just as the Maenad, unsleeping on the mountaintops, stares in wonder as she looks out on the Hebrus and Thrace white with snow, and Rhodope recently traversed by barbarian feet, so I in this lonely place delight in marvelling at the rocks and deserted woods. O Lord of the Naiads and of the Bacchanals who have the strength to uproot tall ash trees with their bare hands, nothing small or in a low style, nothing mortal, shall I sing. It is an intoxicating danger, o God of the wine press, to follow your divinity, wreathing my temples with green vine leaves. ${ }^{9}$

\footnotetext{
rupes.

9 Translated by Niall Rudd (2004).
} 
Odes 3.25 begins with the poet asking where he is being taken: quo me, Bacche, rapis? The privileged position of this sentence calls attention to the relevance of the landscape in the poem. The ambivalent Bacchus is both a wild and a civilizing god, and these contrasting facets tend to be presented in different settings. As a god of the wilderness, Bacchus is often depicted being worshipped in orgiastic rituals in caves, woods and on high mountain peaks. As a civilizing god, he is presented as a patron of wine and a deified hero, to whom libations are offered at public and private banquets. However, as we shall see, the wild and civilizing aspects of Bacchus are often interdependent and overlap each other at various points, resisting rigorous distinctions.

The wild side of Bacchus is prominent in Odes 3.25. The repeated mention of remote places in nature reinforces this idea: the references range from woods, caves and mountaintops (nemus, 2, 13; specus, 2; antrum, 4; ripae/rupes, 13; iugae, 8) to specific regions of Thrace known for their associations with maenadic rituals (river Hebrus and Rodophe Mountains, 1013). In poetry, secluded places in nature, which are often - but not necessarily - associated with Bacchus, may be described as poetic haunts, denoting poetic space/territory. ${ }^{10} \mathrm{It}$ is precisely in these places that Horace most frequently presents Bacchus as a god of poetry. In Epistles 2.2, Bacchus is depicted as a peaceful deity (somno gaudentis et umbra, 76-77) that is worshipped by the writers in a grove (nemus). ${ }^{11}$ There is a sense of otium in

10 For remote places as poetic spaces in Horace, see also.: woods/grove (nemus): Hor., Epist.2.2.76-77; C. 4.3.11, C. 1.1.30-31: me gelidum nemus/Nympharumque leves cum Satyris chori. Cliffs (rupes): C. 2.19.1: Bacchum in remotis ... rupibus. Cave (antrum): C. 2.1.39; C. 3.4.40: Pierio antro; C. 1.5 .3 (with erotic connotations): grato, Pyrrha, sub antro. For the symbolism of the Bacchic cave, cf.: Pailler (1995, 59-77), Lowrie (1997, 323).

11 Hor., Epist. 2.2.76-77: scriptorum chorus omnis amat nemus et fugit urbem, / rite cliens Bacchi somno gaudentis et umbra. For the figure of the poet enjoying nature, cf.: Hor., C. 1.1.19-22; Juvenal 7.58-9; Quintilian, Inst. Or. 10.3.22-4. 
approaching the god as a patron of poetry in this passage that contrasts with the startling and disquieting epiphany of Bacchus in Odes 3.25, which emphasizes the power, the violence and the challenges presented by the god. ${ }^{12}$

\section{Bacchic enthusiasm and poetic furor}

Descriptions of epiphanies (apparitions/manifestations) of deities were widely used by Latin and Greek poets to justify their choices of certain themes, metres or styles of poetry. This topos consists in saying that a deity manifested itself and interfered in the poet's decisions, indicating what treatment should be given to poetry and possibly suggesting a "way" to follow. One of the models for this topos can be found in Callimachus' prologue to the Aetia, in which Apollo appears to the poet and gives him instructions as to how to write poetry, advising him to keep his Muse "slender" and to follow the "untrodden path" (which are usually interpreted respectively as metaphors for elegance and innovation in poetry). ${ }^{13}$ In Odes 3.25, the difference is that Bacchus does not speak to the poet, but - in a much more vehement way than the Callimachaean Apollo - carries him off to remote landscapes in order to write a poem to Augustus.

In both Odes 3.25 and 2.19, in which Bacchus plays the role of god of poetry, the epiphanies of Bacchus are linked with Dionysiac possession and poetic composition. ${ }^{14}$ As we have seen,

12 In Hor., C. 2.19 the epiphany of Bacchus is also disquieting, emphasizing the fear and restlessness triggered by the presence of god with his powerful thyrsus: Parce Liber, parce gravi metuende thyrso (8).

13 Call., Aetia fr. 1.21-28 Pf.. See also: Lucr. 1.925-27: quo nunc instinctus mente vigentil avia Pieridum peragro loca nullius antel trita solo; Virg., Ecl. 6.3.9a. Harrison $(2017,240)$ notes that C. 3.25 "plainly refers to Horace's innovation in the Odes, using the traditional language of untrodden paths which looks back to Lucretius and Callimachus (lines 12-13)".

14 For Bacchus as an epiphanic deity, see Henrichs (1993, 19): "the transformative power of Dionysus is inseparable from his epiphanies”. See also: epiphany of 
in 3.25, Horace's poetic persona declares to be possessed by Bacchus (Bacche ... tuiplenum, 1-2) and then announces that he will sing praises of Augustus. Similarly, in 2.19, the poet claims to be full of Bacchus (plenoque Bacchi pectore, 6) before he starts singing praises of this god. Bacchic possession is described in these odes as a strange state in which the mind is violently shaken and confused with contrasting sensations of pleasure/joy and fear/danger (2.19.5-7: recenti mens trepidat metu ... turbidum laetatur, 3.25.3, 18: mente nova... dulce periculum).$^{15}$

Dionysiac possession was used as a metaphor for poetic enthusiasm by the Greeks as well as the Romans. Plato, for instance, in the Ion, makes Socrates compare epic and lyric poets to possessed Bacchants. ${ }^{16}$ Poetic enthusiasm (or furor poeticus) which can be understood as a state apart from reason and above reason - was not necessarily connected with Dionysus. ${ }^{17}$ The topos of the poet who spoke to or through a deity was widely used by the Greeks. Plato, in the Laws, uses the simile of the poet as a fountain that channels water to describe how poets, out of their senses, received knowledge from the Muse. ${ }^{18}$ Pindar normally appears as an interpreter of - and not possessed by the Muses. ${ }^{19}$

The earliest reference to the notion of poetic enthousiasmos

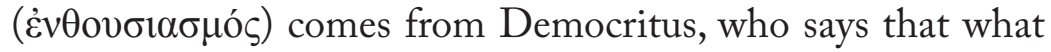
the poet writes with enthusiasm is very beautiful. ${ }^{20}$ Cicero,

Quirinus, in Hor., Serm. 1.10.31-35; of Cupid in Ov., Am. 1.1.1-6.

15 For mente nova as divine possession, cf.: Sen., Ag. 720; Lucan 5.167.

16 Plato, Ion 533.e.4. See also Democritus, fr. 21.

17 For Bacchic enthusiasm and furor poeticus, cf.: Sperduti (1950), Tigerstedt (1970), Aricò (1985), Hunter (2006, 44), Schiesaro (2010, 61-79), Kilpatrick (1986, 19), Rudd (1989, 199), Mckinlay (1953).

18 Plato, Laws 719C.

19 Pindar, fr. 150 S. (137 B.), Pyth. 4.279, Paean 6.6 (fr. 40 B).

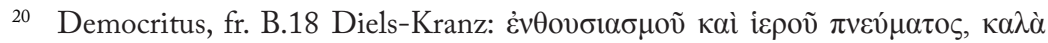

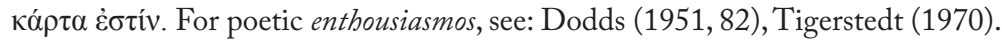


commenting on this passage of Democritus, translates $\dot{\varepsilon} v \theta 0 v \sigma 1 \alpha \sigma \mu o ́ s$ as inflammatio animorum or adflatus furoris, a state of violent mental agitation or wild excitement. ${ }^{21}$ The word enthousiasmos derives from entheos (to be full of a god), and corresponds to the expressions plenoque Bacchipectore (C. 2.19.6) and Bacche tui plenum (C. 3.25.1-2) used by Horace to describe Dionysiac possession. Lucretius was probably the first to use this metaphor in Latin poetry, saying, in De Rerum Natura, that the sharp thyrsus (as a metonymy for Bacchus) infused in his heart the love of the Muses, instigating him to write his poem (sed acri percussit thyrso ... incussit suavem mi in pectus amorem Musarum, 1.922-925). ${ }^{22}$

In Greek poetry, one of the earliest examples of the connection between Bacchus, wine and poetic enthusiasm is from Archilochus, who boasts about his ability to lead the dithyramb of Dionysus when his wits are thunderstruck by wine. ${ }^{23}$ Stephen Harrison has noted that dulce periculum of Odes 3.25.18 "conveys the excitement of poetic inspiration, couched with Horatian irony in language which suggests that the poet's confused enthusiasm

21 Cicero, De Orat. 2.46.194: saepe enim audivi poetam bonum neminem (id quod a Democrito et Platone in scriptis relictum esse dicunt) sine inflammatione animorum existere posse et sine quodam adflatu quasi furoris. Also: De Divin. 1.38.80: negat enim sine furore quemquam poetam magnum esse posse, quod idem dicit Plato. Hor., Ars Po. 295: ingenium misera quia fortunatius arte credit et excludit sanos Helicone poetas Democritus.

22 See also Virg., G. 2.475-76: Me uero primum dulces ante omnia Musae,/ quarum sacra fero ingenti percussus amore.

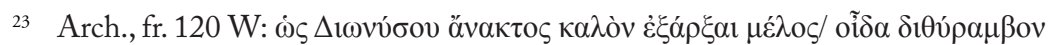

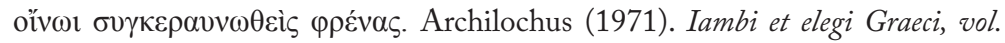
1, ed. West, M.L. Oxford: Clarendon Press. For wine-drinking poets (vinosus, potus) in Horace: Ep. 1.19.1-7: laudibus arguitur vini vinosus; Homerus Ennius ipse pater numquam nisi potus ad armal prosiluit dicenda. For water-drinking poets (aquae potor): Epist. 1.19.8-9: nulla placere diu nec vivere carmina possunt, quae scribuntur aquae potoribus. Sober poets (siccus): C. 1.18.3-4: siccis omnia nam dura deus proposuit. For the topos of wine and water-drinking poets, cf.: Crowther (1979, 1-11), Knox (1985, 107-119). 
may be connected with over-consumption of the munera Bacchi, as befits a symposiastic bard". ${ }^{24}$

There is no doubt that in Odes 3.25 poetic enthusiasm is more closely associated with maenadic possession than with the ecstatic powers of wine. However, orgiastic rituals and winedrinking are connected by the effects, being both described as a combination of contrasting sensations. Both the sweet danger (dulce periculum, 3.25.19) and the confused ecstasy (metu ... turbidum laetatur, 2.19.6-7) of Dionysiac orgies sound like other the expressions used by Horace to describe the frenzy produced by wine, such as lenis tormentum, amabilis insania or dulcis furor. ${ }^{25}$ For instance, in Odes 2.7, Horace refers to the dulcis furor trigerred by wine drinking (non ego sanius/bacchabor Edonis: receptol dulce mibi furere est amico, 26-28). The verb bacchor, which refers to Bacchic mental excitement, is associated with dionysiac experience from both sources, rituals and revels. Horace suggests that his poetic persona will go mad like an Edonian, a people of Thrace who had a reputation for drinking and who were also known for their association with the cult of Dionysus. Another example is Odes 4.12.28, dulce est desipere, in which Horace combines sweetness with madness (desipere, colloquial term that means to be out of mind, lose one's reason) to describe the ecstatic effects of wine.

The term dulcis qualifies other pleasures of the conuiuium besides wine, such as food, love, friendship and poetry. It is an attribute of the god of Love (dulcis Cupidol Amor), who, like dulcis Lyaeus, is also sympotic deity with ecstatic and liberating powers. Horace also uses the word dulcis to qualify his patron and friend Maecenas, who is often depicted enjoying banquets in the poet's company in the Odes and Epodes. Finally, in the Ars

\footnotetext{
24 Stephen Harrison $(1998,675)$.

25 For the paradox of Bacchic excitement, cf.: Hor., C. 3.4.5: amabilis insania; C. 3.19.18: insanire iuvat; C. 3.21.13: lene tormentum. For dulcis furor in Horace, cf. La Penna (1995, 273-275).
} 
Poetica 99, dulcis appears as an essential feature of poetry, which is to delight and to move the affections. ${ }^{26}$

In Horace, serious themes, like war and politics, may also be associated with some form of sweetness or pleasure. ${ }^{27}$ More specifically, an example of the connection between the sweetness of wine, politics and war can be found in the sympotic Epode 9, which is the first example of Bacchic poetics associated with Octavian/Augustus in Horace: curam metumque Caesaris rerum iuvat/ dulci Lyaeo solvere (37-38). As we can see, dulcis Lyaeus helps to release anxieties and fears in times of political uncertainties. ${ }^{28}$ Solvere (which means to loosen, untie or relax) emphasizes an aspect of Bacchus that is already implicit in the etymology of the Greek name Lyaeus ( $\Lambda$ vaĩos, the relaxer, unbender, the one who sets free; a variant of $\lambda$ vios, , deliverer). ${ }^{29}$ Lyaeus' function, in this case, is to liberate from madness

26 For the sweetness of Bacchus/wine, cf. Hor., Epod. 9.37-38: dulcis Lyaeus; C. 3.12.1-2: dulci malal vino lavere; C. 3.13.2: dulci mero; C. 1.7.19: mollis merum. Sweetness of Cupid/love: Hor., C. 4.1.4-5: dulcium/ mater saeva Cupidinum; C. 1.9.15: dulcis amores; Sappho, Frag. 130 Voigt.: 'Еро $\gamma \lambda \nu$ Love). Sweetness of the food: Hor., C. 3.8.6-8: voveram dulcis epulas et album/ Libero caprum prope funeratus/ arboris ictu. Sweetness of Maecenas: Hor., Epist. 1.7.12; C.1.1.2: dulce decus meum. Sweetness of poetry: Hor., Ars Poetica 99: non satis est pulchra esse poemata: dulcia sunto. For the use of dulcis in the Ars Poetica 99, cf. Rudd (1989, 167): "dulcis implies a direct influence on the emotions, perhaps affecting”. For metaphors from food and drink in Horace, cf.: Gowers (1993, 126-179), Bramble (1974, 44-59).

${ }_{27}$ For the topos of the brave soldier who finds satisfaction in giving his life for the good of the patria in Horace, see also: C. 3.19.2, 4.9.51-52. For this topos as a reformulation of Tyrtaeus, cf. Quinn (1980, 245). For instance, the sweetness of dying at war in Odes 3.2 (dulce et decorum est pro patria mori, 13) sounds sublime, evoking the honours dedicated to the heroes who died for their fatherland.

28 For Epode 9 as a sign of Horace's political reconciliation with the Augustan regime, cf. Giusti (2016).

29 For Lyaeus (Bacchus/Liber) as loosener or releaser, see also: Virg., Ecl. 5.69; Hor., C. 1.7.17-23, 2.11.17, 3.8.13-17, 3.21.15-16; Epod. 9.37-38, 13.17-18; Ep. 1.5.16-21: quid non ebrietas dissignat? operta recludit, ... contracta quem non in paupertate solutum? (dissigno, to unseal and reveal something; solutum puns on Lyaeus as releaser). For the releasing effects of wine in Horace, see: Kilpatrick (1986, 64), Putnam (2006, 394), Mayer $(1994,140)$. For the connections be- 
(of civil war), instead of causing it. As we can see, in Horace, the term dulcis is often used to refer to a pleasurable aspect of something (which possibly belongs to the symposium, such as wine, love, poetry or friendship) that helps to counterbalance or relieve affections and impulses (furores) associated with serious themes, like war and politics.

This is how the poet's challenge of following Lenaeus sounds like in Odes 3.25 (dulce periculum est/ o Lenaee, sequi deum, 19-20). The expression dulce periculum combines the pleasure/joy of surrendering to the gifts of the god together with the danger/ fear of approaching his terrifying powers. This paradox suggests the state of mind in which poetry will be conceived, and can also be seen as a metaphor for the pleasure and risk involved in the task of writing poetry in praise of the princeps.

Dionysiac possession: the poet as a Maenad

After announcing that he will sing of Augustus, Horace turns the focus back to his poetic persona, introducing the simile of the poet as Maenad (non secus in iugis/ exsomnis stupet Eubias ... ut mibi .. mirari libet, 8-14). ${ }^{30}$ Maenadic possession is described as a paradoxical state that combines pleasure and astonishment with vigorous action and violence. ${ }^{31}$ Horace suggests that his poetic persona is both amazed and delighted by what he sees at the lonely places of Bacchus, like a sleepless Maenad looking out in wonder (prospiciens, 10) on the remote

tween Liber (the liberator) and Dionysus Eleuthereus (eleutheros, free; patron of the City Dionysia at Athens), see Wiseman (1998,36).

30 The choice of the name Eubias (from euhoe!, the cry of the Bacchants) suggests the excitement of Bacchic possession. For the simile of the poet as a Maenad in Hor., C. 3.25, see Oliensis $(1998,130)$.

31 For Maenadic possession, violence and ecstasy in Greek poetry, see Schelesier (1993, 94-7); for Pentheus impersonating a Maenad in Euripides' Bacchae, see Segal (1982, 28-31). 
landscapes of Thrace. On the other hand, Dionysiac possession also engenders power and violence, which is suggested by words that define the actions and the character of Bacchus (rapio, 1 ; potens, 14) as well as those that refer to the courage (valentes, 15) and the unnatural strength and vigour of the Maenads, who can traverse long distances in ritual dance (pede barbaro, 11) and are capable of uprooting tall trees when possessed by the god (vertere fraxinos, 16).

Potens indicates the power Bacchus holds over his entourage of Bacchants and Naiads. Power and violence are central aspects of Bacchic possession in Odes 3.25, which starts with the poet being dragged by the force of Bacchus (Quo me, Bacche, rapis tui plenum?, 1-2), like a Maenad, without knowing where he is being taken, until he discovers that he will sing praises of Augustus. Therefore, it is worth considering more carefully the use of the verb rapio (which means to take away by force, capture, ravish), an action that usually implies rapidity and violence. ${ }^{32}$ The rapidity implicit in this verb is emphasized by the adjective velox, in line 3 , which, according to Nisbet and Rudd, "refers to the impetus of composition and the dithyrambic rapidity of the ode itself". ${ }^{33}$ On the other hand, the verb rapio also suggests violent action, and places the poet in a passive state in relation to the powers of the god. ${ }^{34}$ This idea is reiterated by the verb ago in the passive form (quae nemora aut quos agor in specus, 2), used in the sense of being carried off and led to do something. ${ }^{35}$

32 For rapio and furor applied to civil war/politics, cf. Hor., Epod. 7.13-14: furorne caecus an rapit vis acrior /an culpa? For the use of rapio in the carpe diem topos, cf.: Hor., C. 4.7.7-8 (the swift passage of time): inmortalia ne speres, monet annus et almum/ quae rapit hora diem; Epod. 13.3-5 (to grasp the opportunity offered by the day): rapiamus, amici, / occasionem de die, dumque virent genual et decet.

33 Nisbet and Rudd (2004, 300).

34 For the vehemence of Bacchus as a god of poetry, cf. Batinski $(1971,371)$.

35 See also the use of the verb ago to describe Amata's state of Dionysian madness in Virgil's Aeneid 7.383-4: non cursu segnior illo per medias urbes agitur populosque 


\section{Bacchus and genre}

Bacchus, as god of poetry, plays an important role in Horace's treatment of the lyric genre. In Odes 2.19, the god allows (fas est, 9,13 ) the poetic persona to sing higher themes in his praise. ${ }^{36}$ In 3.25 , Bacchus literally drags (rapio, 1) Horace to a higher level, urging him to write a panegyric to Augustus. Reaching such heights where Bacchus is worshipped certainly involves many risks and dangers. One of the dangers of facing the challenge posed by the god, which consists in singing higher themes in a new way, can be seen as an allusion to the risk of trying to emulate Pindaric high lyric in the panegyric to Augustus. ${ }^{37}$ Despite the dangers, in 3.25 the poet seals his commitment to Lenaeus (and consequently to Augustus), wreathing his forehead with the vine (cingentem viridi tempora pampino, 20). ${ }^{38}$ So what would be the benefits of following such a dangerous yet delightful path that leads to the remote landscapes of Lenaeus? The answer to this question requires further analysis of some aspects of the Dionysiac experience as it is presented in Horace.

Dionysiac enthusiasm, in both orgiastic rituals and wine-drinking, is said to trigger a state of excitement that easily

ferocis. For the Dionysiac madness of Amata, cf.: Mac Góráin $(2014,218)$.

36 See recusatio in Hor., C. 1.6.10-13, in which the unwarlike lyric Muse stops the poetic persona from writing epic: inbellisque lyrae Musa potens vetat/laudes egregii Caesaris et tuas/ culpa deterere ingeni.

37 For Pindaric associations in Horace, cf.: Hor., C.1.6; 2.20; 3.1; 4.2. For Pindaric associations in C. 3.25, cf. Schiesaro (2009, 68), West (2002, 209), Lowrie (1997, 238-42).

38 Another interpretation of this line (20) is to take cingentem of Bacchus. However, this use would probably give a weaker sense to the passage, since attention is fixed on the poet, especially at the end of the ode. Contrast with the use of the Perf. Part. in the epithet in C. 4.8.33: Liber ornatus viridi tempora pampino. For the use of cingetem in line 20, cf. Nisbet and Rudd (2004,308). See Quinn (2002, $287)$ for the garland as a symbol of the poet's surrender to inspiration. For Hor., C. 3.25 as an odd analogy for the poet's political commitment to Augustus, cf. Nisbet and Rudd (2004, 299). 
leads to excess. Throughout the Odes, Bacchus usually appears as a civilizing figure, provider of numerous benefits, if approached properly. In Odes 1.18, Horace praises the god's gifts provided both at the symposium and in ritual, but warns that no one should cross the limits of the moderate Liber (ac ne quis modici transiliat munera Liberi, 7). Wine in association with the iocus of the sympotic environment may be a remedy for the worries of life. ${ }^{39}$ However, in excess, it may lead to inappropriate and violent behaviour. The episode of the brawl of the Centaurs and the Lapiths, which ends in death, is an exemplum of the excesses of sympotic life. ${ }^{40}$ Therefore, the ambivalent Liber can be either verecundus or inverecundus (modest or immodest), depending on how he is approached. ${ }^{41}$

The overwhelming powers of Bacchus as a leader and patron of poetry are in constant tension with his releasing effects as an orgiastic and sympotic deity. This tension between binding and freeing is a central aspect of the paradox faced by the followers of this god, which consists in freedom in servitude, as suggested in Euripides' Cyclops, that ends with the satyrs happy to be freed from Polyphemus so that they can serve Dionysus again. ${ }^{42}$ As we shall see, by suggesting that he surrenders to Bacchus, Horace hints at his approach both to the lyric genre and to Augustus as a theme of poetry.

39 For wine as a source of iocus (joy, jest) and as a remedy for the worries of life, cf.: Hor., C. 2.11.17: dissipat Eubius curas edaces; C. 3.21.14-16: iocosus Lyaeus; Virg., Ecl. 5.69: et multo in primis bilarans conuiuia Baccho.

40 For the brawl and madness of the Centaurs, cf. Hor., C. 1.18.8-9; 2.12.5-6; Virg., Georg. 2.454-57. For drunken brawls and passionate love, cf. Hor., C. 1.13.10-11: inmodicae mero rixae. For Bacchus and the excesses of sympotic life in Horace, cf. Cucchiarelli $(2011,264)$.

${ }^{41}$ Hor., Epod. 11.13-14 (inverecundus): simul calentis inverecundus deus/fervidiore mero arcana promorat loco. C. 1.27.3-4 (verecundus): verecundumque Bacchum/ sanguineis probibete rixis.

42 Eur., Cycl. 708-9. 
Bacchus is the god of freedom (libertas), and two of his names, often used by Horace in sympotic poems, allude to these liberating powers: the Italic name Liber (the liberator) and the cult-title Lyaeus (the releaser). The liberation granted by the god, among several other possibilities, may affect speech. In Odes 3.21, the joyful (iocosus) Lyaeus, as a metonymy for wine, releases from worries and mellows the sober-minded, causing them to reveal their secret thoughts and intentions: tu sapientium/curas et arcanum iocosol consilium retegis Lyaeo (14-16).

The wine's tongue releasing effect is presented as either beneficial or harmful. In Epistles 1.5.19, one of the benefits of drinking consists in making people eloquent: fecundi calices quem non fecere disertum? (disertum, from dissero: to examine, argue, discuss; to speak, discourse). However, Bacchus' tongue liberating impulse may be associated with lack of restraint in speech. As we have seen above, the fluency in speech caused by ebrietas may unlock secrets (arcana), an effect that is not always considered convenient. An epigram of Meleager refers to the paradoxes of Bacchus as a tongue releaser, saying that although Bacchus is the god of the mysteries, who keeps his own arcana secret, he is less scrupulous regarding other people's secrets. ${ }^{43}$ Let us therefore examine some aspects of the liberating powers of Bacchus associated with poetic libertas or licentia (freedom or frankness of speech) in Horace.

Liber "in excess" may be a source of sarcasm, ridicule, laughter, violence, invective or vituperation, which are characteristic of lower genres. In Odes 1.16, Horace compares the furor poeticus that originates the violent iambus to the mindshaking Dionysiac experience (quatit mentem ... Liber, 5-7) and refers to the passionate frenzy that moves his poetic persona (fervor... misit furentem, 22-25) to write offensive, harsh and fast iambi (criminosi, 2; tristes, 9, 26; celeres, 24).

43 Meleager, A.P. 12.199.5-6. For the relation between Meleager's epigram and Epode 11, see Watson (2003, 371). 
In Satires 1.4, Liber receives the epithet verax (condita ... verax aperit praecordia Liber, 89), which suggests this god's ability to reveal what is hidden and to promote truth-telling (in vino veritas). In this specific example, verax refers to the excessive frankness (licentia) that is typical of satire. ${ }^{44}$ The Dionysiac tongue releasing effect is also described in Epode 11, a sympotic poem in which a comic-iambic facet of Bacchus emerges. ${ }^{45} \mathrm{In}$ this epode - in which Horace expresses concern about poetic composition (scribere versiculos amore percussum gravi, 2) Bacchus is presented as the shameless god (inverecundus deus, 13) who presides over the convivium. ${ }^{46}$ The heat of the wine causes the poetic persona to lose control of speech and reveal secrets (calentis ... fervidiore mero, arcana promorat loco, 13-14).

Another reference to Liber's tongue liberating enthusiasm in this epode is associated with bilis. The expression meis praecordiis libera bilis (liberating rage/bile in my vitals, 15-16) recalls Dionysiac possession in both Odes 3.25 (Bacche tui plenum, 1-2) and 2.19 (plenoque Bacchi pectore, 6). The word libera may

44 Libertas as freedom of speech directly affects the way Horace presents his persona as a satirist. In Satires 1.4, in which Horace tries to define his place in the satirical tradition, Liber appears as the truthful god who unlocks secrets (verax Liber, 89). Horace argues that the poets of Old comedy and Roman satirists, like Lucilius, had freedom in abundance (multa cum libertate notabant, 5), whereas his own libertas was more restricted in terms of personal invective. The setting of this satire is the conuiuium, where the ritual of amicitia is central. Horace defines himself as sanus (129) in contrast with other poets that are compared to abusive dinner guests, who drink freely and make public their friends' secrets (81-91). On Horace's poetic libertas in the Satires, cf. Dessen (1967, 78-9), Schlegel (2000, 103), Oliva Neto (2003, 88-90), Gowers (2003, 127-129), Freudenburg $(2004,15-51)$.

45 Hor., Epod. 11.13-16: simul calentis inverecundus deus/ fervidiore mero arcana promorat loco./'quodsi meis inaestuet praecordiis / libera bilis. For Liber in Hor., Epode 11, see Mankin (1995, 192-201). For the dangers of wine as a tongue loosener, cf. Hor., Ep. 1.18.37-38: arcanum neque tu scrutaberis illius umquam,/ conmissumque teges et vino tortus et ira; $S$. 1.4.84-5: conmissa tacerel qui nequit: bic niger est.

46 See also Ov., Pont. 1.10.29: immodico Lyaeo. 
pun on the god's name, Liber, probably suggesting his role as tongue liberator. ${ }^{47}$ Praecordia, often used in lower genres (notice that this word also appears in Satires 1.4.89, mentioned above), corresponds to pectus as the seat of passions. ${ }^{48}$ And bilis, which can be interpreted as rage (according to the notion that black bile could trigger such affection), may also be associated with poetic furor (enthusiasm/madness). There is a passage of Ps.-Aristotle's Problem 30.1 that connects both bilis and wine with poetic enthusiasm. It says that hot black bile, like wine, would trigger frenzy, which, among other effects, would help with poetic composition. ${ }^{49}$ In Horace, the liberating effects of both wine and bilis may function as sources of poetic furor and licentia/libertas in speech. ${ }^{50}$

Therefore, as regards Bacchic possession, it is a fine line that separates ecstasy from madness, freedom from slavery, and higher from lower genres of poetry. The ambiguities and paradoxes of Bacchus as well as the god's connections with a variety of poetic genres (from tragedy and epic to iambus and comedy) give Horace flexibility to introduce and combine topoi from different sources in his lyric poetry. ${ }^{51}$ In Odes 3.25, Bacchus

47 See Naevius, Palliatae 113 (NB. Paul. Fest. 116M): Líbera linguá loquemur lúdis Liberálibus.

48 Praecordia are literally the vital organs below the heart. For praecordia as seat of the passions, cf. Hor., S. 1.4.89; Epod 5.95.

49 For black bile and frenzy: Ps.-Arist., Problem 30.1.954a.15-25. For frenzy and poetic enthusiasm: Ps.-Arist., Problem 30.1.954a.35. Bilis as rage: Hor., S. 1.9.66:

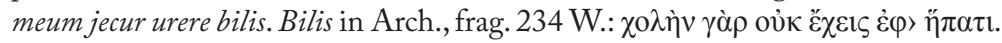
For bilis and poetic enthusiasm, cf. Giusti (forthcoming). "The Metapoetics of Liber-ty: Horace's Bacchic Ship in Seneca's De Tranquillitate Animi”.

50 For poetic libertas in Horace as a prerogative of the poets: cf. Ars Poetica 9-13: poetis audiendi potestas ... veniam petimus. For poetic libertas and licentia in Horace, see also Giusti (forthcoming). "The Metapoetics of Liber-ty: Horace's Bacchic Ship in Seneca's De Tranquillitate Animi”.

51 For the inclusion of topoi from other genres (generic enrichment) in Horace's lyric, cf. Harrison (2007, 168-206); (2017, 243-246). 
particularly propels the poetic persona towards panegyric in lyric verse.

Politics and wine: the symposium as a place to sing of Augustus

Horace stresses both his taste for and his moderation with the gifts of Bacchus, describing the behaviour of his poetic persona as both a symposiast (conviva) and a symposiarch (magister bibendi). As magister bibendi, he stablishes the rules of the symposium, prescribing the proper measures of wine and water to be drunk and trying to control the mood of the guests in order to avoid chaos. As a conviva, his poetic persona may drink large quantities of wine, but chooses very carefully when, what, how and with whom to celebrate and go mad, especially if patrons or friends are involved. ${ }^{52}$

Having the god of freedom under control is the guarantee that excesses in speech will be avoided, especially in connection with Augustus as a subject of poetry. When Horace says that it is dangerous to follow Lenaeus, he may also be suggesting that he must be careful in his approach to his patron, Augustus, so as to avoid revealing what should be kept secret, as if he were dealing with the mysteries of Dionysus himself. ${ }^{53}$ Therefore, as

52 For Horace as symposiast (conviva), see: Hor., C. 4.5.39; 3.8.13-14: sume, Maecenas, cyathos amici/ sospitis centum. For Horace as symposiarch (magister bibendi), see: Hor., C. 1.27.1-4; 3.19.5-18. For the measures of wine and water in Hor., C. 3.19, see Pavlock (2001, 53), Quinn (1980, 277-79). Wine was usually drunk mixed with water, to drink pure wine was considered a barbarian habit. For the right occasion to celebrate, see: Hor., C. 4.12.28: in loco; C. 2.7.27-28: recepto amico. For the duties of the symposiarch, cf.: Cairns (2012, 265), Smith (1984, 259), Nisbet and Rudd (2004, 229).

53 For Horace's political discretion, cf.: Hor., Epist. 1.18.38; Sat. 1.5. For secrecy in the mysteries of Bacchus, cf. Hor., C. 1.18.11-13: non ego te, candide Bassareu,/ invitum quatiam nec variis obsita frondibus/ sub divum rapiam. The secrecy in the mysteries of Demeter can also be seen as a metaphor for political discretion: 
regards freedom of speech (libertas), Horace does not employ the abusive language of invective associated with the iambic-satiric Bacchus in poems addressed to Augustus, but emphasizes the civilizing aspects of the god, who helps to relax and to forget worries about the future, and who aggregates people in joyful celebrations of victories, triumphs and peace. ${ }^{54}$

Having the god of wine as a patron of poetry in Odes 3.25 seems like an opportune way of justifying the praise of Augustus in lyric, a genre that "has fundamentally symposiastic rather than encomiastic associations". ${ }^{55}$ Horace makes the symposium an appropriate environment to sing of Augustus, both in lyric and iambic poetry, linking the relaxing effects of wine with serious themes, like war and politics, by the carpe diem topos. As we have seen, in Epode 9 - published when Actium was still a cause of concern - dulcis Lyaeus (37-38) appears as a remedy for the anxieties and fears for (or of) Caesar's cause. ${ }^{56}$

Another striking example is Odes 1.37 , the well-known sympotic poem that commemorates Augustus' victory in Actium - a decisive battle for Rome, which was made to look like a fight against a foreign enemy personified in the figure of Cleopatra. Andrew Feldherr has noticed that although Bacchus is not literally named in this ode, there are verbal markers of his presence at the beginning and end of the poem. Pede libero, in

Hor. C. 3.2.25-32: vetabo, qui Cereris sacrum/volgarit arcanae; see also: Quinn (2002, 246), Rudd (2004, 145).

54 For wine libations and poetry in praise of the heroes, see Hor., C. 4.5.31-36, 4.15.25-32. For harmless and invective humour in Horace, cf. Oliva Neto (2003, 87-97).

55 Harrison (1998, 675): "is this poem [Odes 3.25] in fact a justification of praising Augustus in lyric, which has fundamentally symposiastic rather than encomiastic associations?"

56 For the fear for (or of) Octavian's cause in Epode 9, see Giusti (2016, 133): "either fear for or fear of Caesar, depending on which side one is on: in any case, a fear which can only be dissolved by Bacchus himself (37-8)". 
line 1 , and triumphus, in line 32, are both linked with dithyramb, a form of Greek lyric composition connected with Dionysus. ${ }^{57}$

In the expression pede libero, in the opening line, libero may pun on Liber as both god of freedom and patron of dithyramb. Therefore, pede libero can be seen as a reference to the metrics of dithyramb (Liber's metrical foot) and also as an allusion to the liberating powers of Liber (foot of freedom) against tyrannical forces threatening Rome. ${ }^{58}$ Dionysiac traits characterize both Octavian and Cleopatra in this poem. ${ }^{59}$ The Egyptian queen is portrayed with eastern and decadent Dionysiac features, as a drunken and mad woman who suddenly becomes sober when faced with the powers of Rome. Octavian, in his turn, resembles the Roman Liber as the new liberator of the Republic, who returns from battle as conqueror of the East. ${ }^{60}$ Therefore, Liber represents the two extremes of libertas in Odes 1.37: liberation from oppression in the figure of Octavian, and licentia that leads to decadence in the figure of Cleopatra.

Odes 1.37 closes with the word triumphus (32), which is connected to the Greek term thriambos, a cult-title of Dionysus that refers to the god's association with triumphal processions. ${ }^{61}$

57 Feldherr (2010, 223). Hor., C. 1.37.1, 32: Nunc est bibendum, nunc pede libero/ pulsanda tellus... deduci superbol non humilis mulier triumpho. For dithyramb as an

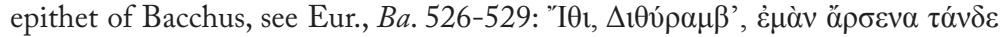

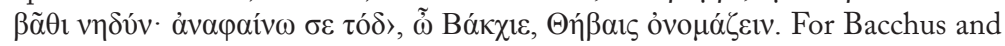
dithyramb, see also Seaford $(2011,192)$.

58 Pede barbaro in Hor., C. 3.25.11, also suggests the idea of Bacchic rhythm, emphasizing the foreign character of the maenadic dance. For the liberating powers of Bacchus against tyranny (pede libero, foot of freedom) in C. 1.37, see also Harrison $(2017,237)$. For the dithyrambic mode and its political meaning in Horace, see Giusti (2016, 131-139).

59 For Octavian vs. Antony/Cleopatra in Hor., C. 1.37, see also Galinsky (2012, 47-58), Oliensis $(1998,138)$.

60 For Bacchus as warrior, conqueror and liberator in Horace, cf. Harrison (2017, 235-240); in Virgil, cf. Mac Góráin (2013).

61 Varro, De Lingua Latina 6.68-69: sic triumphare appellatum, quod cum imperatore milites redeuntes clamitant per urbem in Capitolium eunti '< $i>0$ triumphe'; id a 
This ode marks a turning point in the representation of Bacchus in the Roman world. Bacchus had been Mark Antony's divine model at least since 41 B.C, when he entered Ephesus triumphantly, calling himself the New Dionysus. ${ }^{62}$ After Actium, Bacchus, almost as a spoil of war, becomes a symbol of Caesar's triumph over Antony.

\section{Bacchus, apotheosis and immortality}

Odes 3.25 is also part of the process transformation and assimilation of Bacchus into Augustan imagery. It suggests that the god, as a patron of poetry, supports Augustus, determining that he must be addressed with elevation. So, finally, I would like to consider the role of Bacchus in a question that has been much discussed by scholars: what does Odes 3.25 possibly announce in Horace's work? In other words, what poem(s) would Horace have in mind - if he had any - when he says that he will sing of the apotheosis of Augustus in a new, high and immortal way? ${ }^{33}$ It has been suggested that the so-called Roman Odes (3.1-6) are the poems announced in 3.25. However, one of the problems of this interpretation noticed by scholars is the later position of 3.25 in the book. Nisbet and Rudd think that it is unlikely that this ode foreshadows any particular poem, so a possible explanation for the use of the future forms audiar, loquar and dicam would be that these verbs are made to sound as if they were

$\theta \rho \operatorname{\alpha } \mu \beta \omega$ ac graeco Liberi cognomento potest dictum. See also Diodorus Siculus (4.5.2).

62 For divine models in Augustan poetry,cf. Cucchiarelli (2011.a,157). For Anthony as Dionysus, cf.: Plutarch, Life of Antony 24 and 60; Cassius Dio 50.5.3; Seneca, Suasoriae 1.6: Nam cum Antonius uellet se Liberum patrem dici et hoc nomen statuis subscribi iuberet, habitu quoque et comitatu Liberum imitaretur, occurrerunt uenienti ei Athenienses cum coniugibus et liberis et $\Delta$ lóvvoov salutauerunt.

63 For discussions on this issue, cf. Nisbet and Rudd (2004, 298-299; 2002, 285), Lowrie (1997, 317-321), Fraenkel (1957, 259-260). 
the present, a Pindaric usage.${ }^{64}$ Nevertheless, scholars agree that the poem has a retrospective element, looking back to the theme of Augustus' greatness. So let us look at this issue considering examples in which Bacchus and Augustus are connected through this theme.

The apotheosis of Augustus in 3.25 (stellis inserere et consilio Iovis, 4-5) has clear parallels with Odes 3.3, in which Augustus is compared to Bacchus and other deified heroes (Polux, Hercules and Quirinus). For his services to mankind, Augustus would also achieve immortality, being allowed to participate in the banquet of the gods (quos inter Augustus recumbens/ purpureo bibet ore nectar, 11-12). In this ode, Bacchus receives the epithet pater, which gives an Italic nuance to an Hellenized construction of the god as a conqueror and triumphator, whose civilizing powers are represented by the tigers under the yoke ( hac te merentem, Bacche pater, tuael vexere tigres indocili iugum/ collo trahentes, 13-14). For Horace's audience, the image of Bacchic triumph would evoke associations with Alexander the Great as conqueror of the East. Augustus mirrors the immortal and heroic aspects of Bacchus in 3.3, whereas in 3.25 the poet mirrors Bacchus' power to attribute immortality. ${ }^{65}$ Horace's project of inserting Caesaris decus in the stars in 3.25.4-5 recalls Bacchus' catasterism of Ariadne's honos in Odes 2.19 (beatae coniugis additum stellis

64 For the use of the future as present, see also Hor. C. 1.12.21-22: neque te silebo Liber. For this artifice in Pindar, cf. Ol. 11.14. For the use of future in C. 4.15, cf.: Nisbet and Rudd (2004, 298-299), Quinn $(2002,286)$. Another view: David West (2002, 208-209) interprets loquar as present subjunctive, which would give the passage a tone of prayer instead of sounding like a prediction of success. For him, it would be the poet's appeal to the god to reach the standards of Pindar (the master of dithyramb) in the panegyric to Augustus.

65 For more parallels between Augustus and Bacchus in Hor., C. 3.3 and 3.25, cf.: Lowrie (1997, 317-324), Cucchiarelli (2011, 265), Harrison (2017, 236-240). For Bacchus' yoked tigers as a symbol of civilizing powers, see also Virg., Aen. 6.805. For parallels between Horace and Bacchus as lyric performers and poets of ioci with a young audience of mixed genre, cf.: Hor., C. 2.19.3-4, 3.1.4. 
bonorem, 13-14), "her crown, another sort of decus" . ${ }^{66}$ As Lowrie has pointed out, the apotheosis of Augustus is future in 3.3 (quos inter ... bibet) in part because it depends on the poet's decision to place him among the gods, a decision reached explicitly in 3.25 with inserere (6). ${ }^{67}$

The theme of apotheosis is programmatic in the sense that it places both Augustus and Horace's lyric persona on a higher level. As we have just seen, it connects Augustus and Bacchus as deified hero in Odes 3.3. On the other hand, in Odes 1.1, 2.20 and 3.30, Bacchic motifs suggest the triumph and apotheosis of the poet: in 1.1, Horace envisions himself in the company of Satyrs and Nymphs in a secluded grove from where will reach apotheosis, knocking his head against the stars (feriam sidera vertice, 36). In 2.20, uplifted by Bacchic ecstasy from the previous ode, Horace emphasizes his status as vates (3-4). He anticipates his own immortality as a poet (non ego ... obibo, 6-7), describing his metamorphosis into a swan, an animal that is symbol of both poetry and apotheosis. ${ }^{68}$

And, finally, in 3.30, Horace claims immortality as princeps of lyric poetry, being crowned by the muse Melpomene (non omnis moriar ... lauro cinge volens, Melpomene, comam, 6-16). ${ }^{69}$ Odes 3.30 suggests Horace's conquest of Greek poetry (princeps Aeolium carmen ... deduxisse, 13-14), and echoes Virgil in Georgics 3, who leads the Muses captive in triumphal procession (primus ego ... deducam Musas, 10-11)..$^{70}$ Horace's description of his poetic

66 Harrison $(1998,43)$.

${ }^{67}$ Lowrie (1997, 317-321).

68 For Bacchus as an agent of metamorphosis, responsible for the poet's transformation into a vates, see Schiesaro (2009). For the swan as a symbol of poetry, see also Hor., C. 4.2.25-26.

${ }_{69}$ For Melpomene as Muse of lyric poetry in Horace, cf.: Nisbet and Hubbard (1970, 282); Nisbet and Rudd (2004, 377).

70 Both Hor., C. 3.25 (Caesaris audiar/ aeternum meditans decus/stellis inserere et consilio Iovis, 5-7) and Virg., Georg. 3 (templum de marmore ponam ... in medio 
persona as princeps would inevitably evoke associations with Augustus as a leader of the Romans. ${ }^{71}$ Potens - in ex bumili potens (a man of humble origin risen to power, 12) - suggests Horace's achievement of a position of power as a poet, and also recalls the characterization of Bacchus as a leader of the Maenads and patron of poetry in 3.25 (Naiadum potens Baccharumque, 14-15). ${ }^{72}$ As we can see, Bacchic motifs of power, leadership, triumph, apotheosis and immortality align Horace's lyric persona with the figure of Augustus in these odes.

Later poems in which Bacchus has a role in the praise of Augustus suggest different associations. For example, in Odes 4.15 , the conviuium appears as a place of perpetuation of the memory of Augustus' legacy through poetry. Liber is at the centre of a celebration intended to gather Roman citizens with their families (inter iocosi munera Liberi/ cum prole matronisque nostris, 26-27) to offer libations to the gods and to sing praises of the immortal heroes and of the gens Iulia according to old customs. ${ }^{73}$ Stephen Harrison has pointed out that 4.15 describes "the victories of peace in terms that recall the lyric encomium of the Carmen Saeculare, but which also echoes elements in the Aeneid". ${ }^{74}$

mibi Caesar erit templumque tenebit, 13-15) refer to the immortalization of Augustus through poetry. However, it is easier (but still problematic) to think of the Aeneid as the future panegyric promised in the proem to Georgics 3. As to C. 3.25 , if we consider the use of the future (audiar, dicam, loquar) as a promise to write a future poem about the divinity of Augustus, this promise was apparently not fulfilled.

${ }^{71}$ For Horace as princeps and dux of poetry, see also Hor., Ep. 1.19.21-23. For a discussion on the rivalry and identification between emperor and poet in Augustan poetry, cf. Ziogas (2015).

72 See also Hor., C. 1.6.10: inbellisque lyrae Musa potens, that presides over unmartial lyric poetry.

73 For the custom of celebrating the deeds of men in song at banquets, cf.: Cic., Brutus 75; Tusc. 4.3. For poetry as perpertuation of memory, cf. Martins (2011, 135-139).

74 Harrison (2007, 204). See Virg., Aen. 1.293-4; 8.721-8. 
Despite its encomiastic and epic features, it is unlikely that 4.15 is the poem supposedly promised in 3.25. It was published about ten years later, when neither the political circumstances nor the status of Bacchus in Roman culture were the same. In 4.15, Liber (replaced by Apollo as patron of poetry: Phoebus ... increpuit lyra, 1-2) is still presented as the joyful deity (iocosus Liber, 26) that presides over the conuiuium. ${ }^{75}$ But his functions are different from previous sympotic poems in which he has some kind of association with Augustus. In 4.15, Liber is neither a remedy for the anxieties about Caesar's future, nor the triumphant warrior and liberator, who, as an allegory of Octavian's power, defeats Cleopatra and her Osiris-Bacchus (Mark Antony) in Actium. Odes 4.15 presents a domesticated version of Liber, who symbolizes the otium, the peace and the abudance of a Golden Age. The god's main role is to celebrate the pax Augusta, when threatening Dionysiac elements, such as licentia (10) and madness (furor civilis, 18), are attenuated or eliminated under Caesar's command (custode rerum Caesare, 17$){ }^{76}$

\footnotetext{
75 For Apollo as Horace's patron, see also Hor., C. 4.6.29-30. For Bacchus, poetry and iocus, see Hor., C. 3.21.15: iocosus Lyaeus; 3.3.69: iocosa lyra.

76 For Bacchus' role in Hor., C. 4.15, cf. Quinn $(2002,326)$. For frena licentia as a debasement of political freedom in Hor., C. 4.15.10, cf. Thomas $(2011,265)$. For licentia and civil war, see also Hor., 3.24.29: refrenare licentiam. For licential libertas in politics, cf. Cic., Rep. 1.68.2. For the representations of Pax Augusta in Hor., C. 4.15, cf. Martins (2011,139-154). See also the encomium to Augustus in Hor., C. 4.5, which also focuses on the celebrations of peace and on the prayers and libations offered to Augustus' numen at both public and private banquets. These honours are compared to those dedicated to deified heroes: te multa prece ... Laribus tuum miscet numen, uti Graecial Castoris et magni memor Herculis (32-35). The divinity of Augustus was not officially declared at Rome before his death, so libations and prayers had to be dedicated to his numen in association with the Lares. To confer deification before death would be against the old Republican custom. For the honours dedicated to his numen of Augustus, cf. Hor., Ep. 2.1.5-17; see also Thomas (2011, 160-161).
} 


\section{Conclusion}

There is no neat answer to the question of what poem Horace might be referring to when he announces that he will sing of the apotheosis and immortality of Augustus in Odes 3.25. In fact, this ode may not refer to another poem, being itself an announcement of Augustus' greatness, as some scholars suggest. However, through this analysis, it was possible to notice some associations between 3.25 and other poems that create a mirror effect between poet and patron/princeps through Bacchus.

More specifically, we saw that there is a strong connection and identification between Horace and Augustus through Bacchus as a symbol of triumph, apotheosis and immortality in Horace. Bacchus - who is known for leading his followers to a good end (Liber vota bonos ducit ad exitus) ${ }^{77}$ - points to a promising future for both Augustus and Horace. As a god of poetry, he raises the poet to a place where he can address Augustus with elevation. As a deified hero, he is a model for the encomium of Augustus as a conqueror and leader, and symbol of the princeps' triumph over Mark Antony. And as a sympotic deity, he turns the praise of Augustus into a suitable theme for lyric celebration. The sweetness and iocus of the sympotic Bacchus counterbalances his epic and tragic features, matching Horace's irony and humour, and lending a lighter tone to the risky associations between this god, the poet and the princeps.

By following the paths of Dionysus in Odes 3.25, Horace places Augustus on a higher level, and by doing so he also reaches new heights. However, Dionysiac poetic enthusiasm/furor does not necessarily lead to the sublimity of higher genres, it also belongs to lower genres. Libertas - which, as we have seen, was both a gift of Bacchus and a prerogative of the poets - had to

77 Hor., C. 4.8.34. 
be adapted to the restrictions imposed by the Augustan regime. So Horace carefully keeps the abusive side of Bacchus at a safe distance from Augustus. One the other hand, the sweet side of the god as a patron of poetry allows for more softness in the encomium of Augustus, making it sound more appropriate in lyric.

Furthermore, Horace's choice of Bacchus as a patron of poetry in Odes 3.25 was opportune because, as Stephen Harrison has pointed out, it would add a further deity to be identified with the princeps (avoiding the obvious associations between Augustus and Apollo). ${ }^{78}$ This choice would also contribute to the process of appropriation and reshaping of a symbol previously linked with Mark Antony. In this transformation, Bacchus the god of metamorphosis - had some of his traits enhanced and others attenuated or to become a more suitable figure to symbolize the new rules of the principate as well as the victory and triumph of Augustus over the licentious, excessive and mad aspects of Dionysus that were associated with Mark Antony/ Cleopatra.

Different versions of this paper were delivered at the Augustan Poetry Conference in São Paulo (2015) and at the Institute of Classical Studies Post-graduate Seminar in London (2016). I am grateful to the audiences of these events for their stimulating responses. I would like to thank William Fitzgerald, Stephen Harrison, Elena Giusti, Fiachra Mac Góráin and Andrew Feldherr for their helpful suggestions and comments on earlier drafts of this paper.I extend my thanks to FAPESP (São Paulo Research Foundation) for the financial support for this research; and also to the Institute of Classical Studies, King's College London, University College London and Princeton University, where part of this research was carried out.

78 Harrison (2017, 231-232). 


\section{Bibliography}

\section{Commentaries and translations}

Horace 2002. Horace. Odes III. Dulce Periculum. Text, Translation and Commentary. David West. Oxford: Oxford University Press

1970. A Commentary on Horace: Odes, Book I. R. G. M. Nisbet, M. Hubbard. Oxford: Oxford University Press.

1991. A Commentary on Horace: Odes, Book II. R. G. M. Nisbet, M. Hubbard. Oxford: Oxford University Press.

2004. A Commentary on Horace: Odes, Book III. R. G. M. Nisbet, N. Rudd. Oxford: Oxford University Press.

.2004. Odes and Epodes. Ed. and Transl. by Niall Rudd. Cambridge: Harvard University Press.

1942. Satires, Epistles, Ars Poetica. With an English Translation

by H. Rushton Fairclough. Cambridge: Harvard University Press.

1980. The Odes. Edited with introduction, Revised Text and Commentary by Kenneth Quinn. London: Bristol Classical Press.

.2012. Odes Book I. Cambridge Greek and Latin Classics. Edited by Roland Mayer. Cambridge: Cambridge University Press.

1989. Horace. Epistles Book II and Epistle to the Pisones (Ars

Poetica). Edited by Niall Rudd. Cambridge: Cambridge University Press. 2003. A Commentary on Horace's Epodes. Lindsay Watson. Oxford: Oxford University Press.

1995. Epodes. Edited by D. Mankin. Cambridge: Cambridge University Press.

2011. Horace. Odes, Book IV and Carmen Saeculare. Edited by Richard F. Thomas. Cambridge: Cambridge University Press.

\section{Other works}

Aricò, G. 1985. "Dulce Periculum. Il momento dionisiaco nella lirica oraziana”. In: Nuovo Romanticismo. Numero tre, pp. 7-19.

Batinski, E. E. 1991. "Horace's Rehabilitation of Bacchus". The Classical World, Vol. 84, No. 5, pp. 361-378. 
Bramble,J. C. 1974. Persius and the Programmatic Satire. A Study in Form and Imagery. Cambridge: Cambridge University Press.

Bordoy, F. C. 2013. "Dionysian Enthusiasm in Plato". In: Redefining Dionysos. Edited by A. Bernabé, M. Herrero de Jáuregui, A. I. Jiménez San Cristóbal, R. M. Hernández. Berlin: De Gruyter.

Carpenter, T. H.; Faraone, C. A. 1993. Masks of Dionysus. Ithaca: Cornell University Press.

Commager, S. 1957. "The Function of Wine in Horace's Odes". Transactions and Proceedings of the American Philological Association, Vol. 88, pp. 68-80

Connor, P. J. 1971. "Enthusiasm, Poetry, and Politics: A Consideration of Horace, Odes, III, 25". The American Journal of Philology, Vol. 92, No. 2, pp. 266-274.

Crowther, N. B. 1979. "Water and Wine as Symbols of Inspiration". Mnemosyne, Fourth Series, Vol. 32, Fasc. 1/2, pp.1-11.

Cucchiarelli,A. 2011. "Virgilio e l'invenzione dell'età augustea' (Modelli divini e linguaggio politico dalle Bucoliche alle Georgiche)”. In: LEXIS - Poetica, retorica e comunicazione nella tradizione classica, vol. 29.

Davis, G. (ed.) 2010. A Companion to Horace. Malden: Wiley-Blackwell. Dodds, E. R. 1951. The Greeks and the Irrational. London: University of California Press.

Feldherr, A. 2010. "Dionysiac Poetics and the Memory of Civil War in Horace's Cleopatra Ode". In: Citizens of Discord. Rome and Its Civil Wars. B.W. Breed, C. Damon, A. Rossi (eds.). Oxford: Oxford University Press, pp. 223-323.

Fraenkel, E. 1957. Horace. Oxford: Clarendon Press.

Freudenburg, K. 2004. Satires of Rome. Threatening poses from Lucilius to Juvenal. Cambridge: Cambridge University Press.

Galinsky, K. 2012. Augustus: Introduction to the Life of an Emperor. Cambridge: Cambridge University Press.

Guía, M. V. 2013. "Redefining Dionysos in Athens from the Written Sources: The Lenaia, Iacchos and Attic Women". In: Redefining Dionysos. Edited by A. Bernabé, M. Herrero de Jáuregui, A. I. Jiménez San Cristóbal, R. M. Hernández. Berlin: De Gruyter.

Giusti, E. 2016. "Dithyrambic Iambics: Epode 9 and its General(s') Confusion". In: P. Bather and C. Stocks (eds.). Horace Epodes: 
Contexts, Intertexts, and Reception. Oxford: Oxford University Press, pp. 131-51.

(forthcoming). "The Metapoetics of Liber-ty: Horace's Bacchic Ship in Seneca's De Tranquillitate Animi”. In: M. Stöckinger, K. Winter and T. Zanker (eds.). Horace and Seneca: Interactions, Intertexts, Interpretations. De Gruyter.

. (forthcoming). "Ovid's Ars Poetica: Metapoetic Didactic in the Ars Amatoria”. In: L.G. Canevaro and D. O'Rourke (eds.). Didactic Poetry: Knowledge, Power, Tradition. Classical Press of Wales.

Gowers, E. 1993. The Loaded Table. Representations of Food in Roman Literature. Oxford: Clarendon Press.

Harrison, S. J. 1998. [Review of Horazische Denkfiguren. Theophilie und Theophanie als Medium der poetischen Selbstdarstellung des Odendichters, by Helmut Krasser. Verlag: Göttingen: Vandenhoeck und Ruprecht 1995. Hypomnemata 106. 164 S.]. Gnomon, 70(8), pp. 672-676.

2017. "Horace's Hymn to Bacchus (Odes 2.19): poetics and politics". In: Martins, P.; Hasegawa, A. P.; Oliva Neto,J. A. August Poetry. New Trends and Evaluations. Humanitas: São Paulo, pp. 229-250.

2007. Generic Enrichment in Vergil and Horace. Oxford: Oxford University Press.

Hasegawa, A. P. 2010. Dispositio e Distinção de Gêneros nos Epodos de Horácio. Tese apresentada ao P.P.G. em Letras Clássicas e Vernáculas da FFLCH - USP. São Paulo.

Henrichs, A. 1993. "He has a god in him': Human and divine in the perception of Dionysus. In: Carpenter, T. H.; Faraone, C. A. Masks of Dionysus. Ithaca: Cornell University Press.

Hunter, R. 2006. The Shadow of Callimachus. Cambridge: Cambridge University Press.

Kilpatrick, R. 1975. The Poetry of Friendship. Horace, Epistles I. Edmonton: The University of Alberta Press.

1990. The Poetry of criticism. Horace, Epistles II and Ars Poetica. Edmonton: The University of Alberta Press.

Knox, P. E. 1985. "Wine, Water, and Callimachean Polemics”. Harvard Studies in Classical Pbilology, Vol. 89, pp. 107-119. 
La Penna, A. 1995. "Il Vino di Orazio: nel modus e contro il modus". In: In Vino Veritas. Edited by O. Murray and M. Tecusan. London: The British School at Rome.

Lowrie, M. 1997. Horace's Narrative Odes. Oxford: Clarendon Press.

Mac Góráin, F. 2013. "Virgil's Bacchus and the Roman Republic". In: Augustan Poetry and the Roman Republic, pp. 124-145. Ed. D. Nelis and J. Farrell. Oxford: Oxford University Press.

. 2014. "Apollo and Dionysus in Virgil". In: Incontri di Filologia Classica XII - 2012-2013. Edizione Universitá di Trieste.

Martins, P. 2011. Imagem e poder: consideraçôes sobre a representação de Otávio Augusto. São Paulo: Edusp.

Mckinlay, A. P. 1953. "Bacchus as Inspirer of Literary Art”. The Classical Journal, Vol. 49, No. 3, pp. 101-110+135-136.

Mitchell, E. 2010. "Time for an emperor: old age and the future of the Empire in Horace Odes 4". In: Materiali e discussioni per l'analisi dei testi classici, n. 64, pp. 43-76.

Murray, O.1991. “War and the Symposium”.In:W.J. Slater (ed.).Dining in a Classical Context. Ann Arbor: The University of Michigan Press.

1985. "Symposium and Genre in the Poetry of Horace". The Journal of Roman Studies, Vol. 75, pp. 39-50.

O'Gorman, E. 2002. "Archaism and Historicism in Horace's Odes". In: Clio and the Poets. Augustan Poetry and the Traditions of Ancient Historiography. Ed. by D. S. Levene and D. P. Nelis. Leiden: Brill.

Oliensis, E. 1998. Horace and the Rhetoric of Authority. Cambridge, pp. 127-131.

Oliva Neto, J. A. 2003. "Riso invectivo vs. riso anódino e as espécies de iambo, comédia e sátira”. In: Letras Clássicas, n. 7, p. 77-98.

Pailler, J. M. 1995. Bacchus. Figures et Pouvoirs. Paris: Les Belles Lettres.

Parker, H. N. 1992. "Fish in Trees and Tie-Dyed Sheep: A Function of the Surreal in Roman Poetry”. Arethusa 25, pp. 293-323.

Pavlock, B. 2001. "The Propriety of the Past in Horace Odes 3.19". The American Journal of Philology, Vol. 122, No. 1, pp. 49-66.

Schiesaro, A. 2009. "Horace's Bacchic Poetics". In: L. B. T. Houghton and M.Wyke (eds.). Perceptions of Horace. A Roman Poet and His Readers. Cambridge: Cambridge University Press. 
Schlegel, C. 2000. "Horace and His Fathers: Satires 1.4 and 1.6". The American Journal of Philology, Vol.121, No. 1, pp. 93-119.

Schlesier, R. 1993. "Mixtures of Masks: Maenads as Tragic Models". In: Carpenter, T. H.; Faraone, C. A. (1993). Masks of Dionysus. Ithaca: Cornell University Press, pp. 89-114.

Seaford, R. 2011.Euripides Bacchae. With an introduction and translation by Richard Seaford. Oxford: Oxbow Books.

Segal, C. 1982. Dionysiac Poetics and Euripide's Bacchae. Expanded edition. Princeton: Princeton University Press.

Silk, E. 1969. "Bacchus and the Horatian Recusatio". In: Yale Classical Studies, Studies in Latin Poetry, Vol. 21. Edited by C. Dawson and T. Cole. Cambridge: Cambridge University Press.

Slater,W.J.1991. Dining in a Classical Context. Ann Arbor:The University of Michigan Press.

Sperduti, A. 1950. "The Divine Nature of Poetry in Antiquity". Transactions and Proceedings of the American Philological Association, Vol. 81, pp. 209-240.

Tigerstedt, E. N. 1970. "Furor Poeticus: Poetic Inspiration in Greek Literature before Democritus and Plato". Journal of the History of Ideas. Vol. 31, No. 2, pp. 163-178.

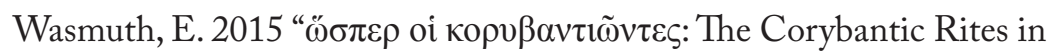
Plato's Dialogues”. $C Q$ n.s. 65, pp. 69-84.

Williams, G. 1986. Tradition and Originality in Roman Poetry. Oxford: Clarendon Press.

Winnington-Ingram, R. P.1969. Euripides and Dionysus. An interpretation of the Bacchae. Amsterdam: Adollf M. Hakkert Publisher.

Wiseman 1998. "Two Plays for the Liberalia”. Roman Drama and Roman History. Exeter: University of Exerter Press.

Xinyue, B. 2015. The divinity of Augustus in the poetry of Vergil, Horace, and Propertius. Doctoral thesis, UCL (University College London).

Ziogas, I. 2015. "The Poet as Prince: Author and Authority under Augustus".In: The Art of Veiled Speech. Self-Censorship from Aristophanes to Hobbes. Edited by Han Batulssen and Peter J. Davis. Philadelphia: University of Pennsylvania Press. 